\title{
Os Processos Constituintes de 1946 e 1988 e a definição do papel do Congresso Nacional na Política Externa Brasileira
}

\author{
National Constituent Assemblies of 1946 and 1988 \\ and the role of Brazilian Congress in Foreign Policy
}

MARCELO COSTA FERREIRA*

Rev. Bras. Polít. Int. 53 (2): 23-48 [2010]

\section{Introdução ${ }^{1}$}

Este artigo tem como objetivo analisar os processos constituintes de 1946 e 1988 nas atribuições internas em termos de Política Externa prescritas pelo próprio Parlamento brasileiro. A perspectiva aqui adotada é a de que boa parte do debate acadêmico sobre o papel do Congresso Nacional na recente política externa brasileira desconsidera que um grupo muito reduzido de constituintes, concentrados seja na Comissão de Sistematização (1988), seja na Comissão de Constituição (1946), deliberaram sobre o tema sem a preocupação de incorporar as propostas das subcomissões em ambos os processos constituintes. Tanto a Assembleia Nacional constituinte de 1946 quanto a de 1988, em parte, tiveram um processo decisório muito concentrado numa "comissão de elaboração do texto constitucional", com poderes muito acentuados em comparação com as comissões temáticas.

Logo, não seria mais adequado inferir que a respectiva delegação ou abdicação deveria ser atribuída às cúpulas dos dois citados Congressos Constituintes, e não à totalidade ou maioria dos constituintes em 1946 e 1988? Em 1946, a Comissão de Constituição praticamente elaborou a maior parte da Constituição Federal dos Estados Unidos do Brasil. Entre 1986 e 1988, a elaboração da Carta Magna da República Federativa do Brasil de 1988 foi caracterizada por dois processos constituintes: o anterior à Resolução no 3 de janeiro de 1988 e o posterior à mesma. No primeiro, (BRASIL: 1987a). havia uma enorme descentralização dos

* Professor de Ciência Política da Universidade Federal de São Paulo - UNIFESP, campus Guarulhos (mcfpolitica@gmail.com).

1 Este artigo é uma versão radicalmente reformulada de um capítulo da minha tese de Doutorado em Ciência Política apresentada à Pontifícia Universidade Católica de São Paulo - PUC-SP. Gostaria de agradecer ao meu orientador, Professor Paulo Resende, pelo apoio. Este estudo foi parcialmente financiado pela Coordenação de Aperfeiçoamento de Pessoal de Nível Superior - Capes. 
trabalhos constituintes em comissões e subcomissões temáticas durante os anos de 1986 e 1987, enquanto em 1988 o processo constituinte foi muito concentrado na Comissão de Sistematização.

Esta pesquisa analisa diários e anais, diários das comissóes pertinentes ao Poder Legislativo e de política externa, ante-projetos e projetos de constituição das Assembleias Nacionais Constituintes de 1946 e 1986/1987, além do material de imprensa e dos discursos de parlamentares que aludem à Assembleia Nacional Constituinte de 1988.

Importa destacar que a quantidade de informação disponível sobre o processo constituinte ocorrido em 1946 é muito menos abundante do que o acontecido em 1988. O segundo processo constituinte foi não só muito mais documentado em termos de textos, depoimentos e entrevistas, mas teve também um tempo de duração muito maior do que o de 1946, além de um acompanhamento muito mais acentuado por parte de lobbies e movimentos organizados. Deve-se ressaltar que o tema da política externa, ao lado da maior participação do Congresso Nacional, teve um espaço muito mais amplo nos debates e embates do processo constituinte de 1988; em contraposição, no processo de 1946, o tema foi pouco discutido.

Este artigo está dividido em três partes. Na primeira, a atenção é voltada para o processo constituinte de 1946; na segunda, para o de 1988; por último, na terceira, é apresentado um resumo do argumento aqui desenvolvido.

\section{O Processo Nacional Constituinte de 1946: a Comissão de Constituição versus a Comissão do Legislativo}

A Assembleia Nacional Constituinte de 1946 foi realizada num momento de afirmação do Legislativo Nacional. Antes disso, em 1937, o Senado Federal, a Câmara dos Deputados, os Senados Estaduais e as Câmaras em níveis estaduais e municipais haviam sido fechados pelo Estado Novo. O parlamento fora reaberto em 1946 num contexto em que a economia e a sociedade brasileiras tinham muito pouco contato com o exterior. A agenda política do momento era a reconstrução da democracia, que surgia como contraposição ao autoritarismo decorrente da revolução de 1930 (BRASIL: 1951; BRASIL: 1948a; BRASIL: 1948a, 2-10; BRASIL: 1948d, 56-68).

Essa conjuntura favoreceu a redação de uma Carta Constitucional que foi a mais parlamentar e liberal da história republicana brasileira (Baaklini: 1993, 31; Hippolito: 2000, 61-68) A citada Constituição Federal de 1946 não só ampliava a atuação legislativa do próprio Congresso, como também restringia apenas ao Poder Executivo a faculdade de enviar uma proposta de orçamento, (Ames, 1986; Brigagão: 1972, 145-155; Lima Junior: 1977, 141-163), apesar das diversas tentativas do Executivo para burlar o controle parlamentar sobre a produção legislativa da Presidência da República. 
A questão do controle do Executivo pelo Legislativo (Draibe: 2004, 299-336), no contexto da agenda política dos trabalhos constituintes de 1946, abrangeu temas como a política orçamentária, produção legislativa - com o fim do DecretoLei, (Pessanha: 2002, 166) -, formas de autoritarismo político e a garantia dos direitos individuais (Lima: 1974, 156). Todavia, a fiscalização do Legislativo sobre o Executivo em temas de política externa e correlatos não foi um dos temas da agenda política daquele momento. O grupo de constituintes a favor do papel mais ativo do Congresso Nacional era reduzido e o processo constituinte de 1946 revela uma total indiferença da maior parte dos congressistas em relação à questão da política externa.

$\mathrm{Na}$ citada assembleia nacional constituinte, a Constituição Federal foi elaborada a partir da Carta Magna de 1934 (Baleeiro: 1999, 13-31); os trabalhos foram coordenados, de maneira centralizadora, por uma Comissão de Constituição, (Silva: 1985, 137-140. ou 1999, 33-53), que, assessorada por diversas subcomissões temáticas, (BRASIL, 1946b), limitou a atuação destas à mera discrição. No nosso caso, vale destacar a subcomissão relativa ao legislativo, dado que não foi sequer instalada uma subcomissão de Relações Exteriores (BRASIL, 1946).

No relatório da Subcomissão do Poder Legislativo relativo ao artigo 65 da CF-1946 - "Compete ao Congresso Nacional, com sanção do Presidente da República" -, existe um inciso c no art. 29 que informa: "É de competência privativa do Congresso Nacional, com sanção do presidente da república: c) legislar sobre comércio exterior e interior, podendo autorizar as limitações exigidas pelo bem público" (BRASIL: 1948c, 47). Entretanto, o projeto original foi modificado, apesar de inicialmente estabelecer um controle da política de comércio exterior do Executivo pelo Legislativo.

Na reunião da Comissão de Constituiçãoo (BRASIL: 1948, 162), foi debatido o capítulo relativo ao legislativo na carta magna de 1946, especificamente o artigo 66: "É da competência exclusiva do Congresso Nacional: I - resolver definitivamente sôbre tratados e convenções celebrados com os estados estrangeiros pelo Presidente da República", então identificado como artigo 28: "É da competência exclusiva do Congresso Nacional: I - resolver definitivamente sôbre tratados e convenções celebrados com nações estrangeiras pelo Presidente da República, inclusive os relativos à paz.” A alínea relativa ao papel passivo do Congresso Nacional em relação a tratados e convenções não provocou nenhum debate ou intervenção dos constituintes, salvo emenda do constituinte Mário Massagão (UDN/SP) (Braga: 1998, 705-707) na Comissão de Constituição: "redija-se a letra a do art. 28 nestes têrmos: a) resolver, definitivamente, sôbre [sic] tratados e convençōes internacionais." Vale mencionar que os parlamentares aprovaram o artigo por unanimidade.

A questão é que o texto constitucional de 1946 não registra a emenda do constituinte Massagão. Além disso, não está disponível na documentação da Constituição de 1946 o processo pelo qual se registrou o Art. 66: "É da 
competência exclusiva do Congresso Nacional: I - resolver definitivamente sôbre [sic] tratados e convenções celebrados com os estados estrangeiros pelo Presidente da República."; ou o Art.87: "Compete privativamente ao Presidente da República: celebrar tratados e convenções internacionais ad referendum do Congresso Nacional." Infere-se que tanto a emenda em nível da comissão de Legislativo sobre o controle do Congresso Nacional na política de Comércio Exterior quanto a Emenda Massagão apresentada na Comissão de Constituição não foram mantidas pela própria Comissão de Constituição, apesar da citada emenda de Massagão ter sido aceita num primeiro debate.

A questão que consiste a lacuna desta análise é a ausência das fontes que descrevam de forma detalhada o processo decisório dos temas de Política Externa na Comissão de Constituição da Assembleia Constituinte de 1946. O relato detalhado de José Duarte sobre os debates na Comissão de Constituição na Assembleia Constituinte de 1946 (Duarte: 1947, 151-222), apresenta um paradoxo e, ao mesmo tempo, uma lacuna a respeito da deliberação: por um lado, ele descreve a apresentação da emenda do constituinte Mario Massagão na Comissão de Constituição como favorável ao papel pró-ativo do Congresso Nacional em Política Externa; por outro, assinala a aprovação sem nenhum debate do inciso em que o Executivo é apontado como a instância que tem poder ativo na assinatura de tratados internacionais. Todavia, a Comissão do Legislativo aprovou uma proposta de legislação muito mais favorável do que aquela defendida pela Comissão de Constituição em relação ao papel pró-ativo do Congresso Nacional.

No texto da Constituição da República dos Estados Unidos do Brasil, há o registro de que o papel fundamental na condução da política externa seria realizado pela Presidência da República. Vale notar que a participação do Congresso acional na Política Externa não foi um dos temas de destaque nos debates da agenda da constituinte de 1946, ao contrário, por exemplo, da questão do orçamento ou da polarização entre a maior ou menor participação do Estado na economia, além da polarização entre forças progressistas e conservadoras. (Braga: 1996, 8-12).

\section{O Processo Nacional Constituinte de 1988:}

a "comissão" de Sistematização e a "subcomissão" do Legislativo versus a "subcomissão" de Soberania e Relações Internacionais

O processo constituinte ocorrido nos anos de 1986, 1987 e 1988 foi muito mais complexo do que o ocorrido na Assembleia Constituinte de 1946. Não se deu uma ruptura radical, como aconteceu com o Estado Novo em 1945/46, com os governos militares instalados em 1964. A própria dinâmica de uma sociedade mais industrializada, urbanizada, multifacetada e articulada significativamente com o exterior do que o Brasil rural da Era Vargas caracterizou essa maior complexidade.

A Assembleia Nacional Constituinte de 1986 foi implantada por um governo que carecia de legitimidade, uma vez que a Presidência da República era exercida 
pelo então vice-presidente José Sarney, que assumiu o cargo após a morte do presidente eleito Tancredo Neves em 1985, tendo entre os seus aliados os militares (Souza: 1991, 311-347; ou Souza e Lamounier, 1989). O governo, entretanto, implantou um plano macroeconômico - Plano Cruzado - que teve grande apoio popular, o que fez com que ele tivesse a quase totalidade dos governos estaduais e a maioria parlamentar nas duas casas do Congresso Nacional (Souza: 1992; Souza e Lamounier: 1991, 319; Coelho: 1999, 116). Todavia, o governo entrou em atrito com os constituintes, pressionando-os para a aprovação do mandato de cinco anos e do presidencialismo, o que caracterizou uma assembleia constituinte sob forte pressão da Presidência da República e dos militares (Fleischer: 1990; Coelho: 1999, 132; ou Lima: 2002, 303).

A Assembleia Nacional Constituinte de 1988 tinha, num primeiro momento, um processo decisório totalmente descentralizado em Comissões e Subcomissōes temáticas (BRASIL, 1987r). Num segundo estágio, a Comissão de Sistematização compatibilizaria as propostas (Resolução no 2/1987), ou seja, o Regimento Interno da Assembleia Nacional Constituinte de 1988, BRASIL (1987a). Esse tipo de procedimento era o oposto da centralização ocorrida no processo constituinte de 1946, onde as comissóes temáticas tinham muito menos poder do que as comissões/subcomissões temáticas da Assembleia Nacional Constituinte de 1988.

A origem do processo, por meio do qual o papel pró-ativo do Congresso Nacional em Política Externa não foi registrado na Carta Magna de 1988, está no início da Assembleia e na Resolução 3, de janeiro de 1988 (BRASIL, 1988a). Uma das propostas iniciais da Assembleia Nacional Constituinte de 1986, encampada pelo seu então presidente, Ulysses Guimarães (PMDB/SP), também presidente da Câmara dos Deputados, afirmava que deveria ser utilizada uma Comissão de Constituição como em 1946. A proposta enfrentou forte resistência, sistematizada no seguinte depoimento do então Deputado Federal Nelson Jobim (PMDB/RS):
"Então o deputado Fernando Lyra saiu à caça de votos para ser presidente da Câmara dizendo o seguinte: Vocês estão vendo o que o Ulysses [Guimarães] quer fazer se for eleito presidente da Câmara e da Constituinte? Ele vai criar os deputados de primeira categoria e os deputados de segunda categoria; os de primeira categoria serão os membros do "clube do poire", que vão integrar essa grande comissão, vão fazer a constituição e vão botá-la goela abaixo de vocês" (Centro Brasileiro de Análise e Planejamento: 1994, 47).

Em suma, esse processo pode ser descrito como: “[...] consideramos ter havido duas constituintes, que talvez possamos chamar Constituinte da sociedade civil e Constituinte do Governo Sarney. O fato de as duas estarem presentes no texto final constitui a base das principais contradições da Constituição de 1988" (Maciel: 1990, 200).

Deve-se ressaltar que, num primeiro momento, a Resolução no 2/1986, ou seja, o Regimento Interno da Assembleia Nacional Constituinte, proporcionava 
um processo constituinte mais democrático, descentralizado nas subcomissões temáticas. Porém, com a imposição da Resolução no 3/1987 (BRASIL: 1988a), ocorreu a concentração, de forma arbitrária, de poder na figura do relator e da Comissão de Sistematização. A atuação de uma Comissão de Sistematização (BRASIL, 1988a e 1988f), com prerrogativas tão expressivas quanto as das Mesas Diretoras do Senado Federal e da Câmara dos Deputados durante o período autoritário de 1964-1984, se realizou na mudança do regimento interno da Constituinte de 1986/1987. Assim: “(...) o processo constituinte praticamente recomeçou, atrasando ainda mais a programação original. Devido aos altos custos impostos pelo novo processo deliberativo após a reforma do regimento na Assembleia Nacional Constituinte, uma solução centralizada tornou-se necessária" (Gomes: 2006, 209). Ora, esse procedimento foi o oposto do princípio amplamente divulgado na retórica vigente à época, segundo o qual: "Dentro do contexto de uma constituinte que era vista como parte de um processo de transição para a democracia, entendia-se que a própria constituinte, para ser legitimamente democrática, deveria rejeitar toda e qualquer forma de delegação dos poderes constituintes a alguns "notáveis". A própria elaboração do seu Regimento Interno foi incluída nesta restrição" (Ibidem, p.19). Segundo o então Presidente da Assembléia Nacional Constituinte, o então Deputado Federal pelo PMDB/SP Ulysses Guimarães No discurso de promulgação do Regimento Interno da citada constituinte em 24/03/1987:

"A engenharia da produção do Texto Magno discrepou da adotada desde 1824, principalmente no que tange, primeiro, à exclusividade de uma Comissão Constitucional, depois porque trabalharam sobre projeto em geral emanado do Executivo. A renovação do Congresso atuou decisivamente para inovar na espécie. Sem texto preexistente, repito, a constituinte será constituinte e societária" (BRASIL: 1987x, 911).

Além disso, os diários da constituinte descrevem imposições, por parte da Mesa Diretora, de procedimentos antirregimentais. Por exemplo, o então senador Mário Covas (PMDB/SP) insistiu que o presidente da Mesa Diretora estava invertendo etapas do processo de votação, tendo como reação a frase de que o mencionado procedimento "era uma questão vencida" (Lima: 2002, 299). Em outras palavras,:

O núcleo do problema residia na forma fragmentada de distribuição do poder decisório e na relação que se estabeleceu entre as etapas bem delimitadas de construção do texto constitucional, isto é, as subcomissões, a comissão temática, a comissão de sistematização e, por fim, o plenário geral, e o grau de legitimidade das deliberações tomadas em cada um desses colegiados (Souza: 2003, 44). 
O conflito mencionado acima derivou da relação entre as duas últimas etapas decisórias. O método de formar o órgão decisório (comissão de sistematização), ao lado da relação que se estabeleceu entre o quorum de maioria absoluta (42 votos) necessário para a aprovação do conjunto das propostas aí reformuladas, além da etapa posterior, que previa o seu exame, agora, pelo corpo de parlamentaresconstituintes reunido em plenário, configuraram um genuíno dilema de representação. Para o plenário alterar as proposiçôes que haviam sido elaboradas e reelaboradas pelas etapas anteriores, exigia-se, também, o quorum de votação de maioria absoluta, ou seja, 252 votos. Emergiu, nesse contexto decisório, um problema que esteve associado ao método representativo que prevaleceu na composição da Comissão de Sistematização, sendo questionada a primazia deste colegiado enquanto grupo de representantes do conjunto dos parlamentaresconstituintes.

Segundo o estudo de Celina de Souza sobre federalismo (Souza: 2001), as propostas da subcomissão também foram muito modificadas pela Comissão de Sistematização. Sandra Gomes, por sua vez, afirma: "Nos tópicos selecionados para análise, podemos ver que as propostas constantes no Cabral II propunham modificações significativas em relação ao projeto da Comissão de Sistematização" (Gomes: 2006, 198). De acordo com a Tabela 1, extraída do próprio texto da mencionada autora, apenas uma - o mandato de cinco anos para o presidente entre onze questões selecionadas passou inalterada pela relatoria ou pela Comissão de Sistematização da Assembleia Nacional Constituinte de 1988. Devemos ressaltar que o choque entre o plenário e a comissão de redação foi mais marcante na votação do parlamentarismo, com explícito apoio da Presidência da República (Souza e Lamounier: 1989, 28), cujo ocupante declarava que a então nova Carta Magna levaria o país à ingovernabilidade, (Medeiros, 2003).

Tabela 1

Evolução de tópicos selecionados durante o processo constituinte, Brasil 1987/1988 (Gomes: 2006, 199).

\begin{tabular}{|l|l|l|l|}
\hline \multicolumn{1}{|c|}{ Assunto } & \multicolumn{1}{|c|}{ Subcomissão } & \multicolumn{1}{|c|}{ Comissões Temáticas } & $\begin{array}{l}\text { Constituição Federal } \\
\text { de } 1988\end{array}$ \\
\hline $\begin{array}{l}\text { Apresentação do } \\
\text { documento final }\end{array}$ & 25 de maio de 1987 & 15 de junho de 1987 & $\begin{array}{l}5 \text { de outubro } \\
\text { de } 1988\end{array}$ \\
\hline Sistema de governo & Semi-presidencial & Presidencial & \\
\hline Mandato presidencial & 5 anos (Sarney 4) & 5 anos & \\
\hline $\begin{array}{l}\text { Jornada de Trabalho } \\
\text { Semanal }\end{array}$ & Máximo de 40 horas & Máximo de 44 horas & \\
\hline $\begin{array}{l}\text { Cálculo para } \\
\text { pagamento de hora } \\
\text { extra }\end{array}$ & $\begin{array}{l}100 \% \text { do valor } \\
\text { ordinário }\end{array}$ & $\begin{array}{l}50 \% \text { do valor ordinário } \\
\text { (mínimo) }\end{array}$ & \\
\hline
\end{tabular}




\begin{tabular}{|c|c|c|c|}
\hline Assunto & Subcomissão & Comissões Temáticas & $\begin{array}{c}\text { Constituição Federal } \\
\text { de } 1988\end{array}$ \\
\hline $\begin{array}{l}\text { Estabilidade no } \\
\text { Emprego }\end{array}$ & $\begin{array}{l}\text { Depois de } 90 \text { dias de } \\
\text { contratação }\end{array}$ & $\begin{array}{l}\text { Valor da indenização } \\
\text { por demissão } \\
\text { imotivada a ser } \\
\text { definido por lei }\end{array}$ & \\
\hline Direito à Greve & Sem restrições & $\begin{array}{l}\text { Serviços essenciais e } \\
\text { servidores públicos será } \\
\text { regulado por lei }\end{array}$ & \\
\hline $\begin{array}{l}\text { Férias e seu } \\
\text { Pagamento }\end{array}$ & $\begin{array}{l}30 \text { dias por ano; } \\
100 \% \text { do salário }\end{array}$ & $\begin{array}{l}\text { Férias por lei e mínimo } \\
\text { de } 1 / 3 \text { do salário } \\
\text { mínimo }\end{array}$ & \\
\hline $\begin{array}{l}\text { Reforma Agrária } \\
\text { (expropiação) }\end{array}$ & $\begin{array}{l}\text { Critério de função } \\
\text { social }\end{array}$ & $\begin{array}{l}\text { Somente não } \\
\text { produtivas }\end{array}$ & $\begin{array}{l}\text { Proibida } \\
\text { expropriação terras } \\
\text { produtivas }\end{array}$ \\
\hline Monopólio Estatal & $\begin{array}{l}\text { Petróleo (exploração e } \\
\text { extração) }\end{array}$ & $\begin{array}{l}\text { Petróleo (exploração } \\
\text { e extração) mais } \\
\text { refinamento e } \\
\text { transporte }\end{array}$ & $\begin{array}{l}\text { Petróleo e } \\
\text { telecomunicações }\end{array}$ \\
\hline $\begin{array}{l}\text { Restrições ao Capital } \\
\text { Estrangeiro }\end{array}$ & $\begin{array}{l}\text { Extração mineral; } \\
\text { saúde }\end{array}$ & $\begin{array}{l}\text { Mineral (a ser regulado } \\
\text { por lei), saúde, } \\
\text { contratos de risco }\end{array}$ & \\
\hline
\end{tabular}

Devemos acrescentar que, de acordo com as reportagens realizadas na época da comemoração dos quinze anos da Constituição Federal de 1988, diversos artigos foram incluídos pela Comissão de Sistematização à revelia dos constituintes. Como exemplo, o ex-senador Jarbas Passarinho (Arena e PDS/PA) revelou que a inclusão dos direitos trabalhistas dos militares foi “... irregular sim, mas era absolutamente necessário" (Época. 2003). De acordo com o então constituinte Nelson Jobim, outros trechos foram incluídos na Carta Magna sem votação (Medeiros, 2003), como o artigo $2^{\circ} \mathrm{da}$ Carta Magna, referente à independência e à harmonia entre os três poderes. A declaração de que nada houve de irregular foi feita por alguns constituintes, mas não foi apoiada por outros parlamentares da Assembleia Nacional Constituinte de 1986. Essa polêmica levou um grupo de advogados paulistas a pedir o impeachment de Nelson Jobim, então no Supremo Tribunal Federal (Ibidem: 319 ou 335; ou Medeiros: 2003, 3).

Outro exemplo desse processo é encontrado nas memórias do Secretário Geral da Mesa Diretora da Câmara dos Deputados entre 1965-1988, Paulo Affonso Martins de Oliveira, ao relatar a criação do processo que gerou a concentração de poder oriunda da Resolução número 3 de 1988. Ao perceber que a estrutura original do processo constituinte poderia elaborar um texto constitucional considerado progressista, um grupo parlamentar denominado Centrão elaborou uma proposta de reforma do regimento interno da Assembleia Nacional Constituinte que permitia uma enorme concentração de poder na Comissão de Sistematização. 
De acordo com as informaçôes presentes no relato de Paulo Affonso, a citada proposta tinha o apoio de $57 \%$ dos parlamentares, 319 deles constituintes (Oliveira: 2005, 166 e 169). Se, por um lado, o grupo de centro/direita era realmente maioria no processo constituinte naquele momento, por que ele apresentava restrições em relação ao processo baseado nas subcomissões vigentes? Se o grupo era maioria, qual motivo levou o Centrão a não apresentar sua visão majoritária no âmbito das subcomissóes? Por outro lado, uma diferença de apenas $6 \%$ deveria ser considerada suficiente para mudar o processo constituinte, em contraposição aos outros $43 \%$ ?

A versão da maioria do Centrão no processo constituinte de 1988 é controversa. Ao ser aprovado o novo regimento interno, as lideranças do citado grupo parlamentar começaram a elaborar as emendas substitutivas, ou seja, um novo projeto constitucional, precisando cumprir o prazo de até a meia-noite do último dia de entrega das emendas. O prazo, contudo, não seria viável, pois o citado grupo não teria tempo para apresentá-las. Se o Centrão era realmente uma maioria incontestável, o procedimento a seguir seria muito diferente daquele descrito (Oliveira: 2005, 173) pelo então secretário geral da Mesa Diretora da Assembleia Nacional Constituinte de 1988, Paulo Affonso:

Fizeram apelo para que eu resolvesse o problema da melhor maneira possível, levando em conta o fato de que uma parcela expressiva da Assembléia não podia deixar de ser representada no processo de elaboração constitucional. Dada a indiscutível relevância do problema, chamei a funcionária que protocolava as emendas na Comissão de Constituição e Justiça para orientá-la no sentido de que saltasse, alternadamente, a numeração de emendas - por exemplo, de 93 para 95, de forma a permitir que as emendas do Centrão fossem recebidas no dia seguinte, e encaixadas nos espaços vazios, entre as que haviam sido apresentadas. Era o único meio de garantir a participação de uma corrente importante na mudança do texto constitucional.

Da mesma forma, o então Deputado Federal Constituinte (PT/SP) Jose Genoíno, em discurso na Câmara dos Deputados no dia 14 de Outubro de 2008:

Numa referência bem genérica, estou aqui a recordar fatos como, por exemplo, a permanente intromissão do Governo no ambiente político da Assembléia Constituinte, que deveria ter sido absolutamente soberana e acabou não sendo. Lembro, especialmente, de questôes como a definição do sistema de governo (o formato de tendência majoritária inicial pró parlamentarismo, que foi revertido a poder de rolo compressor para o de presidencialismo), ou a questão da duração do próprio mandato do Presidente Sarney, [...]. Esse rolo compressor a que me referi teve presença muito bem organizada na Assembléia, embora uma presença amorfa do ponto de vista da representação político-partidária eleita para a finalidade da elaboração constitucional. Recebeu o nome de Centrão, nele configurado todo tipo de ideologia que 
não fosse de esquerda, embora a ideologia nele notoriamente preponderante tenha sido a de um "centro-direitão", avesso a inovações abruptas dos modelos constitucionais, anterior e majoritariamente vigentes no Brasil, produzidos em gabinetes, por redator único ou grupos de redatores fechados e não legitimados para isso por eleição popular (Genoíno, 2008).

O então constituinte e Ministro da Defesa Nelson Jobim, sobre os fatos das alterações feitas pela Comissão de Sistematização nos projetos realizados nas comissões e subcomissões temáticas, na ocasiāo de um seminário sobre a Constituição Federal de 1988, no dia 7 de outubro de 2008, no auditório do jornal Folha de São Paulo, apresenta a sua versão dos fatos:

A versão final da Constituinte seguiu para a Comissão de Redação. Em 2003, Jobim revelou que, quando o texto chegou à comissão, foram acrescentados pontos que não passaram pelos dois turnos de votação no Congresso. "Quando disse isso, a esquerda constitucionalista da avenida Paulista pediu o impeachment contra mim”, disse ontem Jobim. Segundo ele, na comissão foram encontradas várias contradiçōes. Então, disse, os líderes da época discutiram as mudanças necessárias, que foram aprovadas pelo plenário, como se fosse um terceiro turno.

A versão de José Sarney (Folha de São Paulo: 2008, A17), então Presidente da República, depois Presidente do Senado Federal, em depoimento no dia 26 de Agosto de 2008, sobre esses acontecimentos é a seguinte:

A Constituinte de 1988 quis dar um golpe dentro da própria Constituinte. [...] Criou a Comissão de Sistematização, que era composta por 90 congressistas. Esses 90 podiam decidir pela metade, 47 pessoas podiam decidir a matéria. Mas, para derrubar o que a Comissão de Sistematização queria, tinha que ter maioria absoluta no plenário. A matéria votada ali era considerada acabada. Houve uma reação. Como podíamos ter uma Constituição que podia ser votada por 47 pessoas apenas? Houve uma mudança do regimento no qual diz: 'Não, toda matéria tem que ser votada aqui dentro do plenário'. Daí porque eles achavam que essa comissão dos 90 ia fazer um mandato de quatro anos.

Percebe-se, portanto, que a suposta delegação/abdicação política externa, imaginada pelos defensores da tese de que a Carta Magna representa as preferências dos parlamentares política externa, não possui nenhum respaldo empírico. A justificativa dessa assertiva, em termos muitos sintéticos, decorre do fato de que, num primeiro momento, a Subcomissão de Soberania e Relações Internacionais elaborou uma proposta que prescrevia um papel ativo do Congresso Nacional política externa, ao passo que o Regimento Interno da Assembleia Nacional Constituinte de 1988 era regido pela Resolução no 2/1986. Entretanto, conforme 
argumentaremos nos parágrafos a seguir, a partir do momento em que o processo constituinte de 1988 passou a ser regido pela Resolução no 1/1988, a comissão de sistematização desconsiderou o que foi decidido na subcomissão de Soberania e Relações Internacionais, adotando, numa peculiar modalidade de compatibilização, uma proposta de preponderância do Executivo sobre o Legislativo na política externa determinada na subcomissão do Legislativo, proposta feita fora do escopo da respectiva comissão temática e que venceu por apenas um voto.

No contexto da Resolução no 2/1986, há quem diga, baseando-se na análise do projeto da denominada comissão Afonso Arinos (BRASIL. 1987a), que haveria da parte dos constituintes uma tendência para manter a posição passiva do Legislativo em relação a temas de política externa.

Em relação a esse fato, devemos destacar que nenhum congressista, é o que nos indicam os diários das Comissões de Soberania e Relações Internacionais, o Legislativo e o Executivo da Assembléia Nacional Constituinte de 1988, mencionou o citado anteprojeto constitucional. $\mathrm{O}$ único momento (BRASIL: 1987c, 4) em que ele foi comentado ocorreu durante a palestra do então docente de Direito Internacional Público da Uerj, Celso Albuquerque Mello, na audiência pública do dia 28 de Abril de 1987, em que declarou:

O anteprojeto da Comissão presidida pelo eminente professor Afonso Arinos, meu mestre e amigo, contém erros incríveis. Por exemplo, ele diz que o Congresso ratifica tratados. Foi erro de redação. Comentei com ele, que me disse ter sido por causa da pressa. Ratificação não é um ato do Congresso, é ato do poder Executivo, e um ato discricionário do Executivo. Esse é o problema.

Foram elaboradas nove comissões, divididas em mais 24 subcomissões, encarregadas de elaborar os capítulos da Carta Magna, os quais então eram remetidos à Comissão de Sistematização, que estruturava o texto constitucional antes de ser votado em plenário. No caso desta pesquisa, duas subcomissões integram o foco da nossa análise: de um lado, a Subcomissão da Nacionalidade, da Soberania e das Relações Internacionais, integrante da Comissão da Soberania e dos Direitos e Garantias do Homem e da Mulher; e a Subcomissão do Poder Legislativo, pertencente à Comissão da Organização dos Poderes e Sistemas de Governo.

$\mathrm{Na}$ primeira subcomissão, ocorreu um significativo debate sobre a legislação constitucional então vigente, que prescrevia ao Legislativo mero papel de legitimar decisôes sobre tratados internacionais tomadas pela Presidência da República. Nos debates e nas audiências públicas, todos os constituintes que se manifestaram oralmente criticaram o papel passivo do Legislativo na citada questão. Como exemplo, na segunda reunião e primeira audiência pública da subcomissão com o então secretário geral do Itamaraty, embaixador Paulo Tarso Flecha de Lima, realizada em 22 de abril de 1987, o então relator da subcomissão, constituinte João Hermann Neto, comentou que o Executivo, via Itamaraty, nada informava sobre a política externa, citando o caso em que o General Venturi, quando 
questionado sobre a presença de um chefe ou represente estatal brasileiro no Suriname (BRASIL: 1987b, 13), o ameaçou com enquadramento na vigente lei de segurança nacional no plenário da Comissão de Relaçôes Exteriores; ainda na segunda reunião e primeira audiência pública da subcomissão, na qual o docente de direito internacional Celso de Albuquerque Mello realizou uma palestra, o constituinte Aluízio Bezerra reclamou que tratados sobre pesca envolvendo milhões, até mesmo bilhões de dólares foram efetuados pelo Executivo sem a participação do Parlamento (BRASIL: 1987c, 05),; na quinta reunião e quarta audiência pública, realizada em 30 de abril de 1987, após as palestras do docente Carlos Roberto de Siqueira Campos e do então ministro do Supremo Tribunal Federal e professor universitário de Direito Internacional Público da UnB José Francisco Rezek, o constituinte Paulo Macarini mencionou os elevados danos sofridos pelo Brasil com a assinatura, por parte da Presidência da República, do tratado nuclear com a Alemanha, destacando que o mesmo não teria acontecido caso o Congresso Nacional tivesse atribuições de controle dos atos do Executivo em questão de Política Externa, (BRASIL: 1987c, 37) Finalmente, na nona reunião e sétima audiência pública do dia 7 de maio de 1987, na ocasião de uma palestra proferida pelo então ministro das Relações Exteriores, Roberto de Abreu Sodré, os constituintes Sarney Filho e Roberto D'Avila, este então presidente da subcomissão, levantaram questões sobre a relevância e a viabilidade de um controle mais efetivo da assinatura dos tratados, acordos ou contratos internacionais do Executivo brasileiro pelo Parlamento (BRASIL: 1987d, 15-16).

Conforme o descrito, os diários da Assembléia Nacional Constituinte de 1988 não registraram, nos debates e nas audiências públicas da Subcomissão de Nacionalidade, Soberania e Relações Internacionais, nenhuma manifestação a favor da manutenção do papel passivo do Congresso em relação ao Executivo. Na subcomissão do Poder Legislativo, o tema sequer foi abordado; por sua vez, temas como presidencialismo ou parlamentarismo, decretos leis, entre outros, foram o foco do debate.

Outro aspecto da carta constitucional de 1988 envolve a questão da integração regional com a América Latina. Há quem afirme que a Assembléia Nacional Constituinte operou um peculiar mecanismo de delegação ao redigir o artigo $4^{\circ}$ da Constituição Federal, que prescreve a busca pelo Brasil da "integração econômica, política, social e cultural dos povos da América Latina, visando à formação de uma comunidade latino-americana de nações." Conforme será demonstrado no próximo parágrafo, a análise dos documentos do processo constituinte de 1988 revela que a imaginada delegação não ocorreu.

O relator da Subcomissão de Soberania e Relações Internacionais, além da própria subcomissão, nunca inseriram nenhuma intenção parecida com o artigo $4^{\circ}$ da Carta Magna vigente nos anteprojetos da mencionada subcomissão (BRASIL: $1987 \mathrm{~m}$ ou BRASIL, 1987o). De acordo com os Anais/Diários da Assembléia Nacional Constituinte de 1986/1988, na Comissão de Sistematização 
(BRASIL: 1988f, 809-811; 915-924; 1495-1495-1500; 1679-1704; 1741-1745) o então senador Marcondes Gadelha (PFL/PB), membro do Parlamento Latino Americano, mas que nunca pertenceu à Subcomissão de Soberania e Relações Internacionais em 1986/1987, apresentou de sua autoria uma emenda, que consistia exatamente no mencionado artigo integracionista, tendo sido apoiado pelo constituinte Fernando Gasparian. Nesse contexto, (Ibidem, 1494), o relator Bernardo Cabral declarou:

Sr. presidente e Srs. Constituintes, apenas para prestar uma homenagem ao constituinte Marcondes Gadelha, quero dizer que o relator acolhe a emenda em homenagem a S.Exa, pela maneira com que esse eminente constituinte desenvolveu a sua argumentação.

Esse procedimento foi registrado na primeira versão do projeto de Constituição (BRASIL: 1988b) Ora, o parágrafo integracionista foi produto da vontade do relator perante a iniciativa individual de um constituinte. Esse fato é coerente com a observação de Coelho, (Coelho: 1999, 136-137), que destaca:

No limite, o relator da comissão de Sistematização dispunha do poder de anular as decisões tomadas nas comissōes e subcomissōes que não fossem do seu agrado, substituindo-as no seu anteprojeto de constituição pelas emendas de sua preferência derrotadas anteriormente.

Não discutimos o mérito da emenda, mas daí inferir que existiu uma vontade pretérita do poder constituinte de delegar ao Executivo o processo de integração, o que foi apenas o produto da ação de dois constituintes, não corresponde ao que foi relatado nas atas e regimentos da Assembléia Nacional Constituinte que redigiu a Carta Magna de 1988.

O anteprojeto da Subcomissão de Soberania e Relações Internacionais era muito diferente do que o registrado na Constituição Federal de 1988. De acordo com o anteprojeto do relator João Hermann Neto, descrito na Tabela 2, o Congresso Nacional teria um papel próativo em temas de Política Externa. O Executivo, antes de ratificar qualquer tratado internacional, deveria antes ter autorização do Congresso Nacional. 
Tabela 2

Atribuições do Congresso Nacional em relação a assinaturas de tratados e acompanhamento da política externa efetivada pelo Executivo - Anteprojeto da Subcomissão da Nacionalidade, da Soberania e das Relações Internacionais da Assembléia Nacional Constituinte de 1988 (Assembléia Nacional Constituinte: 1987o, 16-17).

\begin{tabular}{|c|c|c|}
\hline Art. 26 & $\begin{array}{l}\text { Das atribuições } \\
\text { do Presidente da } \\
\text { República }\end{array}$ & $\begin{array}{l}\text { "Compete privativamente ao Presidente da República: } \\
\mathrm{VI} \text { - negociar a celebração de tratados e outros compromissos } \\
\text { internacionais quando autorizados por lei ou por tratado anterior, } \\
\text { submetendo-os, nos demais casos, à aprovação do Congresso } \\
\text { Nacional, antes de ratifica-los". }\end{array}$ \\
\hline Art. 30 & $\begin{array}{c}\text { Das atribuições } \\
\text { do Congresso } \\
\text { Nacional }\end{array}$ & $\begin{array}{l}\text { "Compete privativamente ao Congresso Nacional: } \\
\text { II - resolver sobre tratados e compromissos internacionais nego- } \\
\text { ciados pelo Presidente da República, salvo quando previamente } \\
\text { autorizados por lei ou tratado } \\
\text { IV - informar-se de todos os tratados e compromissos } \\
\text { internacionais negociados pelo Presidente da República e que } \\
\text { independam de aprovação prévia do Poder Legislativo para fins } \\
\text { de ratificação } \\
\text { VI-10 os contratos mencionados no inciso VI do presente artigo, } \\
\text { quando onerem financeiramente a união ou estipulem garantias } \\
\text { pelo tesouro nacional, só terão validade após a promulgação do } \\
\text { respectivo Decreto-Legislativo de aprovação". }\end{array}$ \\
\hline Art. 31 & & $\begin{array}{l}\text { "O Congresso Nacional, no seu regimento interno, estabelecerá } \\
\text { normas e procedimentos para a instalação de um comitê de } \\
\text { acompanhamento e fiscalização das relações internacionais } \\
\text { que o capacitem a exercer de forma eficiente, permanente } \\
\text { e ágil a competência que lhe é conferida pelo artigo } 30 \text { desta } \\
\text { constituição". }\end{array}$ \\
\hline
\end{tabular}

O projeto da subcomissão, apresentado em anexo a este artigo, propõe uma ruptura com a legislação constitucional vigente em relação ao papel passivo do Congresso Nacional quando comparado com o papel da Presidência da República. As cartas Magnas de 1946 ou 1967, ou até mesmo o sugestão contida na proposta de constituição federal elaborada pela comissão Arinos, tradicionalmente reiteraram o papel próativo do Executivo, conforme a Tabela 3. 
Tabela 3

Comparação do papel do Congresso nas cartas magnas de 1946, 1967 e 1988 (BRASIL, 2001[1988], 1978 [1967], 1964 [1946]).

\begin{tabular}{|c|c|l|}
\hline Ano & Artigo & \multicolumn{1}{c|}{ Ementa } \\
\hline \multirow{4}{*}{ C.F. 1988 } & Art. 84 & $\begin{array}{l}\text { "Compete privativamente ao Presidente da República: VIII - celebrar } \\
\text { tratados, convenções e atos internacionais, sujeitos a referendo do } \\
\text { Congresso Nacional"; }\end{array}$ \\
\cline { 2 - 4 } & Art. 49 & $\begin{array}{l}\text { "É da competência exclusiva do Congresso Nacional: I - resolver } \\
\text { definitivamente sobre tratados, acordos ou atos internacionais que } \\
\text { acarretem encargos ou compromissos gravosos ao patrimônio nacional"; }\end{array}$ \\
\hline \multirow{2}{*}{ C.F. 1967 Art.83 } & $\begin{array}{l}\text { Art.80 } \\
\text { "Compete privativamente ao Presidente: VIII - celebrar tratados, conven- } \\
\text { çôes e atos internacionais, ad referendum do Congresso Nacional"; }\end{array}$ & $\begin{array}{l}\text { "Compete à União: I - manter relações com Estados estrangeiros e } \\
\text { com eles celebrar tratados e convenções; participar de organizações } \\
\text { internacionais"; }\end{array}$ \\
\hline \multirow{2}{*}{ C.F. 1946 Art.47 } & Art. 66 & $\begin{array}{l}\text { "É da competência exclusiva do Congresso Nacional: } \\
\text { I- resolver definitivamente sôbre tratados e convenções celebrados com } \\
\text { os estados estrangeiros pelo Presidente da República"; }\end{array}$ \\
\cline { 2 - 4 } & Art.87 & $\begin{array}{l}\text { "Compete privativamente ao Presidente da República: } \\
\text { celebrar tratados e convenções internacionais ad referendum do } \\
\text { Congresso Nacional". }\end{array}$ \\
\hline
\end{tabular}

Contudo, o mesmo não ocorreu na nona reunião da Subcomissão do Poder Legislativo realizada no dia 22 de Maio de 1987, (BRASIL: 1987k, 6-33). No anteprojeto da Subcomissão de Poder Legislativo, o então constituinte Fernando Henrique Cardoso propôs uma emenda cuja leitura foi precedida do seguinte comentário (Ibidem 12), do constituinte Bocayuva Cunha, presidente da Subcomissão do Poder Legislativo:

Peço a atenção dos Srs. Constituintes, porque essa emenda é extremamente importante e tem, inclusive, o apoio do Ministério das Relaçôes Exteriores, que julga fundamental a aprovação dessa redação.

A mencionada emenda teve a seguinte redação:

Resolver, definitivamente, sobre tratados, convençōes e acordos internacionais celebrados pelo poder Executivo, bem como, na forma e nos limites fixados em Decreto-Legislativo, sobre todos os atos internacionais que impliquem compromisso de qualquer espécie para o país.

A justificativa para a emenda foi: 
$\mathrm{Na}$ medida em que as relações internacionais se tornaram mais densas e complexas, passaram a gerar uma variedade de atos e documentos oficiais de hierarquia inferior aos tratados, convenções e acordos. Aqui não se propóe que todos eles passem pelo crivo do Legislativo, o que emperraria a condução da política externa. O próprio Legislativo, no entanto, deve determinar, soberanamente, quais as classes de atos internacionais que passarão pelo seu crivo e até onde irá a autonomia do Poder Executivo nessa matéria (BRASIL, ibdem).

O então constituinte Itamar Franco destacou que também apresentou uma emenda, mas o presidente da subcomissão teve uma posição próativa em favor da emenda de Fernando Henrique Cardoso (BRASIL: 1987k, ibidem); como congressista, Itamar Franco sugeriu a substituição, na emenda de Fernando Henrique, do termo "resolver" por "aprovar previamente", apresentando uma incisiva defesa oral da maior participação do Congresso Nacional na fiscalização dos atos do Executivo; a seguir, durante o processo de votação, se posicionou contra. Em decorrência, o presidente da subcomissão permitiu ao constituinte Itamar Fraco que lesse a sua emenda, em relação à qual foi então indagado pelo constituinte Nelson Wedekin sobre a extensão dos atos internacionais mencionados: convençôes, acordos e tratados.

Em seguida, após defesa contundente da emenda de Fernando Henrique Cardoso, feita pelo relator José Jorge, foi encaminhada a votação: três constituintes votaram a favor da emenda, enquanto outros treze a rejeitaram. Depois de curto debate, chegou a vez da votação da emenda do constituinte Itamar Franco: oito constituintes votaram a favor, outros oito contra. Dado o empate, o voto de minerva do presidente da subcomissão foi contra a emenda de Itamar Franco, o que permitiu a vitória da emenda de Fernando Henrique Cardoso, com quem relator da comissão, José Jorge, estava de acordo.

No contexto da Resolução no 1/1988 (BRASIL, 1988a), na qual a Comissão de Sistematização passou a ter muito mais poder do que o permitido na Resolução no 2/1986, devemos destacar que o aspecto mais grave se relaciona ao fato de que a Mesa Diretora da Assembléia Nacional Constituinte de 1988 tinha a atribuição regimental de compatibilizar propostas discordantes. De acordo com o documento: "Na elaboração do anteprojeto, a Comissão de Sistematização compatibilizará as matérias aprovadas nas comissões." Todavia, a Mesa Diretora não cumpriu sua respectiva determinação regimental, pois, se a maioria da Subcomissão de Relaçôes Exteriores aprovou o controle do Executivo pelo Legislativo quanto à Política Externa, e a Subcomissão de Legislativo ficou dividida ao meio, o correto seria considerar como válido a posição de controle, que tinha o apoio da maior parte dos constituintes. Porém, a Comissão de Sistematização e o relator da constituinte, numa estranha modalidade de compatibilização, sacramentaram a proposta que tinha o apoio da menor parte dos congressistas e que acabou inscrita na Carta Magna de 1988. 
A Tabela 4 descreve a grande disparidade entre o que foi discutido no âmbito das subcomissões e o que acabou sendo registrado no texto constitucional de 1988. É nítida a diferença entre a proposta da Subcomissão de Soberania e Relações Exteriores e a da Subcomissão do Poder Legislativo, apesar de a posição passiva do legislativo federal ter sido aprovada por apenas um voto nesta última comissão. Todavia, desde o Projeto de Constituição A até o registro final, o texto constitucional acabou registrando uma posição tradicional a respeito do papel passivo do Congresso, a qual não foi apoiada ao passar pela Subcomissão de Soberania e Relações Exteriores.

Tabela 4

Alterações no processo de elaboração constituinte sobre Política Externa, relação Executivo e Legislativo, e integração regional na Assembléia Nacional Constituinte de 1988, (BRASIL, 1987m, 1987n, 1987o e 1987p); (BRASIL, 1988d, 1988e, 1988f, 1988g, 1988h, 1988i) e BRASIL (2001a)

\begin{tabular}{|c|c|c|c|}
\hline & $\begin{array}{l}\text { Subcomissão de Soberania } \\
\text { e Relações Exteriores }\end{array}$ & $\begin{array}{l}\text { Subcomissão do } \\
\text { Poder Legislativo }\end{array}$ & Comissão de Redação \\
\hline $\begin{array}{l}\text { Anteprojeto } \\
\text { do relator }\end{array}$ & $\begin{array}{l}\text { Art. } 26 \text { "compete } \\
\text { privadamente ao chefe } \\
\text { de Estado: } \\
\text { III - estabelecer, ouvido } \\
\text { o Congresso nacional, } \\
\text { as diretrizes da política } \\
\text { externa"; } \\
\text { Art. 30. "Compete } \\
\text { privadamente ao } \\
\text { Congresso Nacional: } \\
\text { II - resolver sobre } \\
\text { tratados e compromissos } \\
\text { internacionais negociados } \\
\text { pelo chefe de estado, } \\
\text { salvo quando previamente } \\
\text { autorizado por lei ou } \\
\text { tratado". }\end{array}$ & & \\
\hline $\begin{array}{l}\text { Anteprojeto } \\
\text { da } \\
\text { subcomissão }\end{array}$ & $\begin{array}{l}\text { Art. } 26 \text { "compete } \\
\text { privadamente ao chefe de } \\
\text { Estado: III - estabelecer, } \\
\text { ouvido o Congresso } \\
\text { nacional, as diretrizes da } \\
\text { política externa"; } \\
\text { VI - negociar e } \\
\text { celebrar tratados e } \\
\text { outros compromissos } \\
\text { internacionais quando } \\
\text { autorizados por lei ou } \\
\text { por tratado anterior, } \\
\text { submetendo-os nos } \\
\text { demais casos, à aprovação } \\
\text { do Congresso Nacional, } \\
\text { antes de ratifica-los". }\end{array}$ & $\begin{array}{l}\text { Art. } 5 \text { "é de } \\
\text { competência exclusiva } \\
\text { do Congresso } \\
\text { nacional: I- resolver, } \\
\text { definitivamente, } \\
\text { sobre os tratados, } \\
\text { convenções e acordos } \\
\text { internacionais } \\
\text { celebrados pelo } \\
\text { presidente da } \\
\text { república, bem como } \\
\text { sobre os atos deles } \\
\text { decorrentes, que só } \\
\text { terão vigência com a } \\
\text { publicação do } \\
\text { Decreto-Legislativo de } \\
\text { aprovação". }\end{array}$ & \\
\hline
\end{tabular}




\begin{tabular}{|c|c|c|c|}
\hline & $\begin{array}{l}\text { Subcomissão de Soberania } \\
\text { e Relações Exteriores }\end{array}$ & $\begin{array}{l}\text { Subcomissão do } \\
\text { Poder Legislativo }\end{array}$ & Comissão de Redação \\
\hline $\begin{array}{c}\text { Projetos de } \\
\text { Constituição } \\
\text { A }\end{array}$ & & & $\begin{array}{l}\text { Art. } 59 \text { "É de competência } \\
\text { exclusiva do Congresso } \\
\text { nacional, I - aprovar ou não } \\
\text { tratados, convenções e acordos } \\
\text { internacionais celebrados pelo } \\
\text { presidente da república ou } \\
\text { atos que acarretem encargos } \\
\text { ou compromissos gravosos ao } \\
\text { patrimônio nacional"; } \\
\text { Art. 95. Compete privadamente } \\
\text { ao presidente da república XIII - } \\
\text { "celebrar tratados, convençôes } \\
\text { e atos internacionais, com } \\
\text { o referendo do Congresso } \\
\text { Nacional"; }\end{array}$ \\
\hline B & & & $\begin{array}{l}\text { Art. 50. É da competência } \\
\text { exclusiva do Congresso Nacional: } \\
\text { I - "Resolver definitivamente } \\
\text { sobre tratados e acordo } \\
\text { internacionais ou atos que } \\
\text { acarretem encargos ou } \\
\text { compromissos gravosos ao } \\
\text { patrimônio nacional". } \\
\text { Art. 86. VIII anterior, art. } 95\end{array}$ \\
\hline$C$ & & & $\begin{array}{l}\text { Art. 3, parágrafo único: } \\
\text { "A República Federativa do Brasil } \\
\text { buscará a integração econômica, } \\
\text { política, social e cultural dos } \\
\text { povos da América Latina, visando } \\
\text { à formação de uma comunidade } \\
\text { latino-americana de nações"; } \\
\text { Art. } 84 \text {. VIII. celebrar tratados, } \\
\text { convenções e atos internacionais, } \\
\text { com o referendo do Congresso } \\
\text { Nacional. }\end{array}$ \\
\hline D & & & $\begin{array}{l}\text { Art. } 49 \text {. Resolver definitivamente } \\
\text { sobre tratados, acordo ou atos } \\
\text { que acarretem encargos ou } \\
\text { compromissos gravosos ao } \\
\text { patrimônio nacional; } \\
\text { Art. 84. VII - celebrar tratados, } \\
\text { convenções e atos internacionais, } \\
\text { com o referendo do Congresso } \\
\text { Nacional. }\end{array}$ \\
\hline $\begin{array}{l}\text { Constituição } \\
\text { Versão final }\end{array}$ & & & $\begin{array}{l}\text { Art. } 91 \text {. XII - celebrar tratados, } \\
\text { convençôes e atos internacionais, } \\
\text { ad referendum do Congresso } \\
\text { Nacional. }\end{array}$ \\
\hline
\end{tabular}


A análise da Tabela 4, que descreve a evolução da proposta constituinte relativa à relação entre o Executivo e o Legislativo Federal em termos de política externa, mostra que, desde a Subcomissão de Soberania e Relações Exteriores e a Subcomissão do Poder Legislativo até o texto que foi registrado na Carta Constitucional, existe uma grande diferença entre o ponto de partida e a etapa final.

A grande mudança ocorrida diz respeito ao papel do Congresso Nacional, que, de ativo, é alterado para passivo em relação ao Executivo. As primeiras etapas registravam o papel mais ativo do Legislativo, ressaltada a posição da Comissão do Legislativo, que não havia sido registrada em nível de relatoria, mas surgiu na etapa de relatório da comissão. Contudo, a proposta tradicional de primazia da Presidência da República sobre o Congresso, presente nas Constituições Federais de 1946 e 1967, novamente se manteve.

Isso ocorreu porque o processo decisório da Assembléia Nacional Constituinte de 1988 aconteceu de modo centralizado, tendo sido retirado o poder das comissões temáticas e reduzido ao mínimo o poder individual de atuação de cada constituinte. Logo, não foram os constituintes que delegaram ou abdicaram, mas as respectivas relatorias e Mesa Diretora que determinaram, em direção contrária ao que fora debatido no projeto da Subcomissão da Nacionalidade, da Soberania e das Relações Internacionais na Assembléia Nacional Constituinte de 1988, o papel passivo do Congresso Nacional Brasileiro em relação à Política Externa.

Todavia, uma análise minuciosa das atas das comissões do Legislativo, Executivo e da Comissão de Sistematização - além dos respectivos anteprojetos, projetos e versões de projetos de Constituição -, revela que o texto constitucional de 1988 representa muito mais as preferências dos integrantes da Mesa da Comissão de Sistematização da Assembléia Nacional Constituinte do que os projetos gestados nas subcomissões temáticas, configurando uma clara violação do regimento interno da Assembléia Nacional Constituinte. A Comissão de Sistematização deveria compatibilizar as propostas das comissões temáticas; no entanto, ela fez o oposto, desfigurando completamente as preferências dos constituintes.

\section{Conclusão}

Este estudo analisou o processo constituinte de 1946 e o de 1988 procurando discutir a definição constitucional do papel do Congresso Nacional Brasileiro em relação à Política Externa Brasileira. Vimos que, em 1946, o tema não fez parte da agenda dos debates; além disso, o citado processo constituinte foi muito pouco documentado em comparação com o ocorrido em 1988. Vimos também que a Assembleia Constituinte iniciada em 1986 despertou um interesse muito maior em parte dos parlamentares, além de ter sido mais bem documentada do que elaboração da Carta Magna de 1946.

A análise comparada, entretanto, dos anais e diários das Assembléias Constituintes de 1946 e de 1988 revela que, apesar de os legisladores da CF/1988 
terem tido um papel muito mais ativo do que os seus pares de 1946 na construção de um aparato jurídico constitucional que garantisse ao Parlamento brasileiro pleno papel de fiscalizador dos atos do Executivo, ambos os textos constitucionais não refletem - necessariamente - qualquer intenção pretérita dos constituintes com o propósito de subordinar o Congresso Nacional ao papel de mero coadjuvante nas determinações da política externa. Em 1946, o tema foi tratado com indiferença, embora tenham ocorrido manifestações parlamentares a favor de maior participação do Legislativo tanto na Comissão do Legislativo quanto na própria Comissão de Constituição. Todavia, a parca documentação sobre esse processo dificulta uma análise mais detalhada.

Percebe-se, portanto, que a análise efetuada neste artigo sobre a definição do papel do Congresso Nacional em relação à Política Externa, além de sua relação com o Executivo no processo constituinte, revela que quem delegou ou retirou o papel ativo do parlamento não foi a Assembléia Nacional Constituinte de 1986, mas a Comissão de Sistematização da Assembleia Nacional Constituinte, quanto a isso fazendo nítido contraste com a Subcomissão de Soberania e Relações Exteriores. Infelizmente, não foi identificada nas fontes desta pesquisa nenhuma manifestação de conjunto dos Constituintes em favor do texto registrado na Constituição Federal da República Federativa do Brasil de 1988 sobre a relação Legislativo, Executivo e política externa.

No caso específico do processo constituinte de 1988, a afirmação de que a Assembléia Nacional Constituinte de 1988 delegou ou abdicou das prerrogativas do Legislativo em prol das atribuiçôes do Executivo é muito mais controversa do que para o caso de 1946. A elaboração da Carta Magna de 1988 se deu de tal modo que as preferências individuais dos constituintes pouco aparecem no texto constitucional de 1988. De acordo com o estudo de Sandra Gomes (2006, 194), 54\% dos constituintes em 1987 eram a favor de algum tipo de parlamentarismo; no entanto, aprovaram o presidencialismo; o voto distrital tinha o apoio de $63 \%$ dos parlamentares; mesmo assim, não foi implantado, apesar de o então presidente da Assembléia Nacional Constituinte ter declarado que "o voto distrital é um fato consumado." Em outras palavras, a fala do então Senador (PFL/RJ) 'Afonso Arinos, presidente da Comissão de Sistematização da Assembléia Nacional Constituinte de 1986 (BRASIL: 1988b, 916), resume a natureza do processo:

Este assunto, para mim, é crucial. A lei que S. Ex.a invocou tem o meu nome. Fui eu quem pôs, na constituição de 1967, o princípio constitucional oriundo dessa lei, que não era constitucional. Eu criei a lei, coloquei-a na constituição, portanto, tenho o direito de tomar esta decisão. E esta está tomada. Quis dar toda a liberdade à votação [sic]. 


\section{Referência bibliográficas}

ABREU, Alzira Alves; BELOCH, Israel; LATTMAN-WELTMAN, Fernando. Dicionário histórico biográfico pós-1930. CD-ROM. Centro de Pesquisa e Documentação da Fundação Getúlio Vargas. 2001.

AMES, Barry. O congresso e a política orçamentária no Brasil durante o regime pluripartidário. Dados, Vol. 29, no 2, 1986, p. 177-205.

BAAKLINI, A. O congresso e o sistema politico brasileiro. Rio de Janeiro: Paz e Terra, 1993, p. 31

BALEEIRO, A. A constituição de 1946. In: BALEEIRO, A. e SOBRINHO, B. L. Constituiçōes brasileiras: 1946. Brasília: Senado Federal, Centro de estudos estratégicos do MCT e ESAF/ MF, 1999, p. 13-31.

BRAGA, S. S. Quem foi quem na Assembléia Constituinte de 1946: um perfil socioeconômico e regional da Constituinte de 1946. Brasília: Câmara dos Deputados/Centro de Documentação e Informação, 1998, p. 705-707.

BRAGA, S. S. A Constituinte de 1946 e a nova ordem econômica e social do pós-Segunda Guerra Mundial. Revista de Sociologia e Política, Curitiba, números 6 e 7, 1996, p. 8-12.

BRIGAGÃO, Nancy. Nota sobre créditos especiais. Dados, no 9, 1972, p. 145-155.

BRASIL. Congresso Nacional. Assembleia Nacional Constituinte (1988). Constituição da República Federativa do Brasil de 5 de Outubro de 1988. Atualizada até a emenda constitucional 31/2000 e emenda constitucional de revisão no 6/94. Brasília: Senado Federal, secretaria especial de editoração e publicações, 2001a..

BRASIL. Congresso Nacional, Assembléia Nacional Constituinte de 1988. Regimento interno da Assembléia Nacional Constituinte: resolução no 3, de 05 de Janeiro de 1988. Diário da Assembléia Nacional Constituinte, Brasília, Ano II, no 163, 6 de Janeiro de 1988a.

BRASIL. Congresso Nacional. Assembleia Nacional Constituinte. Projeto de constituição (A). Comissão de sistematização: Presidente: Afonso Arinos e Relator, Bernardo Cabral. Brasília, Novembro 1988b.

BRASIL. Congresso Nacional. Assembleia Nacional Constituinte. Projeto de constituição (B). Comissão de sistematização: Presidente: Afonso Arinos e Relator, Bernardo Cabral. Brasília, 1988c.

BRASIL. Congresso Nacional. Assembleia Constituinte de 1988. Projeto de constituição (C). Comissão de sistematização: Presidente: Afonso Arinos e Relator Bernardo Cabral. Brasília, 1988d.

BRASIL. Congresso Nacional. Assembleia Constituinte de 1988. Projeto e constituição (D). Comissão de sistematização: Presidente: Afonso Arinos e Relator Bernardo Cabral. Brasília, 1988e.

BRASIL. Congresso Nacional. Assembléia Nacional Constituinte de 1988. Comissão de sistematização. Ata de votação do projeto de constituição do Senhor relator Bernardo Cabral: 32o Reunião extraordinária. Atas das Comissóes. Suplemento ao no 171 do Diário da Assembléia Nacional Constituinte de 1988. Brasília, Congresso Nacional, Ano II, 27 de Janeiro de 1988, p. 809-811; 915-924; 1495-1495-1500; 1679-1704;1741-1745. $1988 \mathrm{f}$.

BRASIL. Congresso Nacional. Assembleia Constituinte de 1987. Regimento interno da Assembléia Nacional Constituinte: resolução n. 20, de 24 de Março de 1987. Diário da Assembleia Nacional Constituinte. 25 de Março. Brasília, Ano I, no 33. 1987a. 
BRASIL. Congresso Nacional. Assembléia Nacional Constituinte de 1988. Ata das $1^{\text {a }}$ e $2^{\text {a }}$ reuniōes da subcomissão de nacionalidade, da soberania e das relações internacionais em 07 e 22 de Abril, $1^{\circ}$ reunião e $2^{\circ}$ reunião, de audiência pública. In: BRASIL. Congresso Nacional. Atas das Comissóes. Suplemento ao no 53 do Diário da Assembléia Nacional Constituinte de 1988. Brasília, Congresso Nacional, Ano I, 1 de Maio, 1987b. p. 7-15.

BRASIL. Congresso Nacional. Assembléia Nacional Constituinte de 1988. Atas das 3a , 4a $5^{a}$, $6^{\circ}$ e $7^{\circ}$ reuniôes da subcomissão de nacionalidade, da soberania e das relações internacionais. In: BRASIL. Atas das Comissóes. Suplemento ao $n^{\circ} 66$ do Diário da Assembléia Nacional Constituinte de 1988. Brasília, Congresso Nacional, Ano I, 27 de Maio de 1987. 1987c. p.1-59.

BRASIL. Congresso Nacional. Assembléia Nacional Constituinte de 1988. Atas das 8a , 9a e $10^{\circ}$ reuniões da subcomissão de nacionalidade, da soberania e das relaçoos internacionais. In: BRASIL. Atas das Comissões. Suplemento ao no 82 do Diário da Assembléia Nacional Constituinte de 1988. Brasília, Congresso Nacional, Ano I. 24 de Junho de 1987, p. 2-32. 1987d.

BRASIL. Congresso Nacional. Assembléia Nacional Constituinte de 1988. Atas das 11a, $12^{\mathrm{a}}$, $13^{\mathrm{a}}, 14^{\mathrm{a}}, 15^{\mathrm{a}}$ e $16^{\mathrm{a}}$ reunióes da subcomissão de nacionalidade, da soberania e das relaçóes internacionais. In: BRASIL. Congresso Nacional. Atas das Comissões. Suplemento ao $n^{o} 83$ do Diário da Assembléia Nacional Constituinte de 1988. Brasília, Congresso Nacional, Ano I, 25 de Junho de 1987. 1987e. p1-20.

BRASIL. Assembléia Nacional Constituinte de 1988. Atas das $1^{\mathrm{a}}, 2^{\mathrm{a}}$, $3^{\mathrm{a}}$ e $4^{\mathrm{a}}$ reuniōes da subcomissão do poder Legislativo. In: BRASIL. Congresso Nacional. Atas das Comissões. Suplemento ao no 62 do Diário da Assembléia Nacional Constituinte de 1988. Brasília, Congresso Nacional, Ano I, 1 de Maio. p. 37-92. 1987f.

BRASIL. Congresso Nacional. Assembléia Nacional Constituinte de 1988. Ata da 9o reunião da subcomissão de Executivo. Atas das Comissóes. Suplemento ao no 114 do Diário da Assembléia Nacional Constituinte de 1988. Brasília, Congresso Nacional, Ano I, 24 de Julho de 1987, p. 59-88. $1987 \mathrm{~g}$.

BRASIL. Assembléia Nacional Constituinte de 1988. Atas das $1^{\mathrm{a}}, 2^{\mathrm{a}}, 3^{\mathrm{a}}$ e $4^{\mathrm{a}}$ reuniōes extraordinárias da subcomissão do poder Legislativo. Atas das Comissões. Suplemento ao $n^{\circ} 63$ do Diário da Assembléia Nacional Constituinte de 1988. Brasília, Congresso Nacional, Ano I, 21 de Maio de 1987, p. 37-92. 1987h.

BRASIL. Assembléia Nacional Constituinte de 1988. Atas das 5a, 6a e $7^{\text {a }}$ reuniões extraordinárias da subcomissão do poder Legislativo. Atas das Comissões. Suplemento ao $n^{\circ} 66$ do Diário da Assembléia Nacional Constituinte de 1988. Brasília, Congresso Nacional, Ano I, 27 de Maio de 1987, p. 43-77. 1987i.

BRASIL. Assembléia Nacional Constituinte de 1988. Atas das $8^{a}$ reunião extraordinária da subcomissão do poder Legislativo. Atas das Comissóes. Suplemento ao no 96 do Diário da Assembléia Nacional Constituinte de 1988. Brasília, Congresso Nacional, Ano I, 17 de Julho de 1987, p. 57-65. 1987j.

BRASIL. Assembléia Nacional Constituinte de 1988. Atas das 9a reunião extraordinária da subcomissão do poder Legislativo. Atas das Comissóes. Suplemento ao no 103 do Diário da Assembléia Nacional Constituinte de 1988. Brasília, Congresso Nacional, Ano I, 24 de Julho de 1987, p. 6-33. $1987 \mathrm{k}$.

BRASIL. Assembléia Nacional Constituinte de 1988. Atas das $10^{\mathrm{a}}$ e $11^{\mathrm{a}}$ reuniōes extraordinárias da subcomissão do poder Legislativo. Atas das Comissões. Suplemento ao $n^{\circ} 66$ do Diário da Assembléia Nacional Constituinte de 1988. Brasília, Congresso Nacional, Ano I, 27 de Maio de 1987, p. 204-218. 19871. 
BRASIL. Assembléia Nacional Constituinte de 1988. Anteprojeto de constituição: anteprojeto do relator. Subcomissão da Nacionalidade, da Soberania e das Relações Internacionais. Atas das comissóes: suplemento ao $n^{\circ} 83$. Brasília, $1987 \mathrm{~m}$ p 2-5.

BRASIL. Congresso Nacional. Assembléia Nacional Constituinte de 1988. "Anteprojeto de constituição: anteprojeto do relator”. Subcomissão do Poder Executivo. Brasília: 1987n.

BRASIL. Assembléia Nacional Constituinte de 1988. Anteprojeto de constituição: anteprojeto da comissão. Subcomissão da Nacionalidade, da Soberania e das Relações Internacionais. Atas das comissóes: suplemento ao $n^{\circ}$ 83. Brasília, 1987o. p.15-17.

BRASIL. Assembleia Nacional Constituinte de 1988. Anteprojeto de constituição: anteprojeto da comissão. Subcomissão do Poder Legislativo. Brasília, 1987p.

BRASIL. Congresso Nacional. Assembleia Nacional Constituinte (1987). Anteprojeto de constituição: anteprojeto do relator. Subcomissão da Nacionalidade, da Soberania e das Relações Internacionais. Brasília, 1987. 1987q.

BRASIL. Congresso Nacional. Assembleia Nacional Constituinte. Anteprojeto de constituição: anteprojeto da comissão. Subcomissão da Nacionalidade, da Soberania e das Relaçóes Internacionais. Brasília, 1987r.

BRASIL. Congresso Nacional. Assembleia Nacional Constituinte. Anteprojeto de constituição: anteprojeto da comissão. Subcomissão do Poder Legislativo. Brasília, 1987s.

BRASIL. Congresso Nacional. Assembleia Nacional Constituinte. Anteprojeto de constituição: anteprojeto da comissão. Subcomissão do Poder Executivo. Brasília, 1987t.

.BRASIL. Congresso Nacional. Assembleia Constituinte de 1988. Anteprojeto de constituição: anteprojeto do relator. Subcomissão do Poder Legislativo. Brasília, 1987u.

BRASIL. Comissão Provisória de Estudos Constitucionais. Anteprojeto constitucional. Decreto $n^{o}$. 91.450, de 18 de Julho de 1985. Brasília, Comissão Provisória de Estudos Constitucionais, $1987 \mathrm{v}$.

BRASIL. Congresso Nacional. Assembléia Nacional Constituinte de 1988. "discurso do Presidente da Assembleia Nacional Constituinte na promulgação do respectivo Regimento Interno em 24/03/1987”. Diário da Assembleia Nacional Constituinte. 25 de Março. Brasília, Ano I, no 33. 1987x.

BRASIL. Congresso Nacional. Assembleia Nacional Constituinte de 1967. Constituição da República Federativa do Brasil de 24 de Janeiro de 1967. Atualizada até a emenda constitucional $n^{o}$ 12, de 17/10/1978. Brasília, Departamento de Imprensa Nacional, 1978.

BRASIL. Congresso Nacional. Assembleia Constituinte de 1946. Constituição dos Estados Unidos do Brasil de 18 de Setembro de 1946. Atualizada até a emenda constitucional no 10 de 9/11/1964. Brasília: Câmara dos Deputados, diretoria de documentação e publicidade, 1964.

BRASIL. Congresso Nacional. Assembleia Constituinte de 1946. Anais da Assembleia Nacional Constituinte (1946). Redação de anais e documentos parlamentares. Rio de Janeiro: Imprensa nacional, 1951. V. I ao XXVI.

BRASIL. Congresso Nacional. Assembleia Constituinte de 1946. Ata da $18^{a}$ reunião da comissão de constituição. In: Anais da comissão de constituição. Redação de anais e documentos parlamentares. Rio de Janeiro: Imprensa nacional, 1948a.

BRASIL. Congresso Nacional. Assembleia Constituinte de 1946. Primeira subcomissão: da organização federal. In: Anais da comissão de constituição: pareceres e relatórios das 
subcomissões. Redação de anais e documentos parlamentares. Rio de Janeiro: Imprensa nacional, 1948b.

BRASIL. Congresso Nacional. Assembleia Constituinte de 1946. Quarta subcomissão: do poder Executivo. In: Anais da comissão de constituição: pareceres e relatórios das subcomissões. Redação de anais e documentos parlamentares. Rio de Janeiro: Imprensa nacional, p. 56-68. $1948 \mathrm{c}$.

BRASIL. Congresso Nacional. Assembleia Constituinte de 1946. Terceira subcomissão: do poder Legislativo. Anais da comissão de constituição: pareceres e relatórios das subcomissões. Redação de anais e documentos parlamentares. Rio de Janeiro: Imprensa nacional, 1948d.

BRASIL. Congresso Nacional. Assembleia Constituinte., "Terceira subcomissão: do poder Legislativo" In Anais da comissão de constituição: pareceres e relatórios das subcomissões. Redação de anais e documentos parlamentares. Imprensa nacional: Rio de Janeiro. 1948e.

BRASIL. Congresso Nacional. Assembleia Constituinte de 1946. Regimento interno: resolução $n^{\circ} 1$, de 12 de Março de 1946. Rio de Janeiro: Imprensa nacional, 1946a.

BRASIL. Congresso Nacional. Assembleia Constituinte de 1946. Diário da Assembléia [Diário da Assembléia Nacional Constituinte de 1946]. Capital Federal [Rio de Janeiro]: Imprensa nacional, ano I, no 49, terça-feira, 16 de Abril, 1946b.

CACHAPUZ, Antonio Medeiros. O poder Legislativo e os tratados internacionais. Porto Alegre: Editora LPM/Instituto dos Advogados do Rio Grande do Sul, 1983, p. 110-113.

CENTRO BRASILEIRO DE PESQUISA E PLANEJAMENTO. O desafio do Congresso Nacional: mudanças internas e fortalecimento institucional. Cadernos de pesquisa, São Paulo, no 3, Novembro. 1994.

COELHO, R. C. Partidos politicos, Maiorias parlamentares e tomada de decisão na constituinte. 289 páginas. Tese de Doutorado em Ciência Política. Faculdade de Filosofia, Letras e Ciências Humanas da Universidade de São Paulo. São Paulo, 1999.

DUARTE, J. Constituição Brasileira de 1946: exegese dos textos a luz dos trabalhos da Assembleia Constituinte. Rio de Janeiro: Imprensa Nacional, 1947, v. 2, 151-222.

DRAIBE, S. Rumos e Metamorfoses: Estado e industrialização no Brasil 1930/1960. São Paulo: Paz e Terra, 2004, p. 299-336.

ÉPOCA. A prova dos abusos: constituição impressa na gráfica do Banco do Nordeste, em 1988, não contém adulteraçôes feitas ao texto aprovado no congresso. Revista Época, p. 75-76, 13 de Outubro 2003.

ÉPOCA. Juristas pedem impeachment de Jobim por artigos não votados na Constituição. Revista Época, Cidade, 30 de Outubro de 2003. Disponível em: < http://revistaepoca.globo. com/Revista/Epoca/0,,EDT0-6009,00.html > Acesso em: 21 de Março de 2010.

FLEISCHER, D. The constituent assembly and the transformation strategy: attempts to shift political power from the presidency to the congress. In: Graham,Lawrence e Wilson, Robert. The political economy of Brazil:public policies in an era of transition. Austin: The University of Texas Press, 1990, p. 210-258.

FOLHA DE SÃO PAULO. Ex-Presidente [José Sarney] afirma ser contra mudanças na atual lei da Anistia. Folha de São Paulo, São Paulo, 27 de Agosto de 2008. p. A17.

GENOÍNO, J. Discurso no grande expediente da sessão ordinária da Câmara dos Deputados no dia 14 de Outubro de 2008. In:BRASIL. CONGRESSO NACIONAL. CÂMARA DOS 
DEPUTADOS. Diário da Câmara dos Deputados. Brasília, Ano LXIII, n. 170, p. 4342643432, Quarta-Feira, 15 de Outubro de 2008.

MEDEIROS, L. Passando a limpo: diário da Constituinte comprova que artigo 2 foi incluído sem votação em plenário. O Globo, Rio de Janeiro, 7 de Outubro de 2003. Constituiçãa 15 anos: caderno especial, p. 2.

MEDEIROS, Lydia. Jobim revela uma parte do pacto que fez com Ulysses: ministro do STF conta que trechos da carta não foram à votação: "você se lembra bem como este artigo entrou?". O Globo, Rio de Janeiro, 5 de Outubro de 2003. Constituição 15 anos: caderno especial, p. 3.

LIMA JUNIOR, O. B. Mudança política e processo decisório: análise da política orçamentária brasileira. Dados, Rio de Janeiro, no 14, p.141-163, 1977.

HIPPOLITO, Lucia. O buraco é mais embaixo: divagações sobre as obscenas relações entre Executivo e Legislativo no Brasil. Insight/Inteligência. Maio/Junho/Julho, 2000. p. 61-68.

LIMA, Hermes. Travessia: memórias. Rio de Janeiro: Livraria Jose Olympio, 1974.

PESSANHA, Charles. O poder Executivo e o processo Legislativo nas constituições brasileiras: teoria e prática. In: VIANNA, L. W. A democracia e os três poderes no Brasil. Belo Horizonte: Editora da UFMG, 2002, p. 141-194.

SILVA, Helio. Constituição de 1946. In: As constituições do Brasil. Rio de Janeiro: Editora Globo, 1985, p. 137-140. SOBRINHO, Antônio. Constituição de 1946. In: BALEEIRO, A. e SOBRINHO, B. L. Constituiçôes brasileiras: 1946. Brasília: Senado Federal, Centro de estudos estratégicos do MCT e ESAF/MF, 1999, p. 33-53.

Souza, Amaury. Democracia e Reforma Institucional no Brasil: uma cultura política em mudança. Dados, Rio de Janeiro, v. 34, no 3. p. 311-347, 1991.

Souza, Amaury. O sistema político partidário. In: JAGUARIBE, H. (org) Sociedade, estado e partidos na atualidade brasileira. Rio de Janeiro: Paz e Terra, 1992, p. 157-198.

Souza, Amaury. e LAMOUNIER, Bolivar. "Democracia e Reforma Institucional no Brasil: uma cultura política em mudança”. Dados. Vol. 34, no 3, 1991, pp. 311-347.

A feitura da nova constituição: um reexame da cultura política Brasileira. Planejamento e Políticas Públicas, no2, Dez. 1989, p. 17-38.

LIMA, Luziano. A atuação da esquerda no processo constituinte: (1986-1988). 2002. Dissertação de Mestrado em Ciência Política. Instituto de Filosofia e Ciências Humanas da Universidade de Campinas. Campinas, 2002, p. 303.

MACIEL, Maria. Constituinte e transição. Sociedade e Estado, Brasília, v. 5, n. 2, 1990.

GOMES, Sandra. O Impacto das Regras de Organização do Processo Legislativo no Comportamento dos Parlamentares: um estudo de caso da Assembléia Constituinte (1987-1988). Dados, Rio de Janeiro, v. 49, 2006, p. 193-224,.

SOUZA, Celina. Federalismo e descentralização na constituição de 1988: processo decisório, conflitos e alianças. Dados, Rio de Janeiro, v. 44, no 3, 2001, p. 513-560.

Oliveira, Paulo. O Congresso em meio século: depoimento a Tarciso Holanda. Brasília: Editora da Câmara dos Deputados, Coordenação de Publicações, 2005.

Recebido em 03 de novembro de 2009 Aprovado em 29 de março de 2010 


\section{Resumo}

Este artigo analisa os processos constituintes brasileiros de 1946 e 1988 no aspecto da definição constitucional do papel do Congresso Nacional na Política Externa. A Assembleia Nacional Constituinte de 1946 não apresenta grande interesse dos parlamentares pelo tema, ao passo que o mesmo não ocorre na de 1988. Contudo, existe uma grande diferença entre as preferências dos constituintes e as que foram registradas nas Cartas Magnas de 1946 e 1988. Esse fato decorre do contexto histórico no qual a ruptura com os governos autoritários militares mantém a estrutura hierarquizada do parlamento constituinte, no qual a Comissão de Sistematização seguiu a tradição do Executivo com papel preponderante na execução da Política Externa Brasileira.

\section{Abstract}

This research analyses the constituent process of 1946 to 1988 in Brazil concerning the role of Congress in Foreign Policy. In 1946 the National Constituent Assembly did not receive great interest from congressmen; however in 1988 many deputies had significant roles in that process. This finding is related to the historical process concerned with Brazil's path to democracy while its hierarchical congress structure was maintained by the Constituent Assembly of 1988.

Palavras-chave: Assembleia Nacional Constituinte; Congresso Nacional; Política Externa.

Key-words: National Constituent Assembly; National Congress; Foreign Policy. 